\title{
CONCEPTUAL METAPHORS IN G. BYRON'S POETRY AND ITS UKRAINIAN TRANSLATIONS
}

\section{Chendey N. V.}

\section{INTRODUCTION}

This research examines the mechanisms of conceptual metaphors elaboration with special reference to George Gordon Byron's romantic poetry and its Ukrainian translations.

Studies of metaphor have been predominantly dedicated to issues ranging from meaning, structure, components, analogies, typology to the role of metaphors as speech ornaments. These studies, however, neglected the exploration of the continuous connection of metaphors as mental or picturesque representations of the real world and the language used to verbalize these pictures in words ${ }^{1}$.

Despite the majority of literature available on the literary aspects of this linguistic phenomenon, very little research has been done on a cognitive and cultural translation of metaphors. Contemporary studies on metaphor tend to show how metaphors reflect cognitive and cultural human experiences encoded by language as a means of recording human experience and how culture models and constrains this cognition ${ }^{2}$. In particular, this research follows a cognitive approach to poetic metaphors elaboration and translation, especially from and into culturally distinct languages, such as English and Ukrainian.

The most productive within an anthropologic approach to language study proves to be the linguistic and cultural theory of metaphor. Hence, to solve a problem of language and culture interconnection seems to be crucial in recent multiple linguistic works. The study of metaphor has revealed a limited number of possible metaphoric expressions found in a given language. This fact is explained by culturally specified nature of metaphor, advocating an idea that "only images rooted in cultural traditions and native speakers' consciousness can function and develop in language” ${ }^{3}$. Metaphor serves a prism through which human beings view

${ }^{1}$ Lacoff G. The Contemporary Theory of Metaphor / G. Lacoff // Metaphor and Thought / Ed. by Andrew Ortony. 2-nd edition. Cambridge : Cambridge University Press, 1993. P. 202-251.

${ }^{2}$ Katan D. Translating Cultures: An Introduction for Translators, Interpreters and Mediators / D. Katan. Manchester : ST Jerome Publishing, 1999. P. 40.

${ }^{3}$ Quinn N. The cultural basis of metaphor / N. Quinn // Beyond metaphor: the theory of tropes in anthropology. Stanford, 1991. P. 63. 
the world, reflecting specific national vision in an inner language form. V.A. Maslova is a proponent of the theory that studies metaphor as a mode of culture representation. In her opinion, a cultural component of a lexeme presupposes a culturally marked connotation that emerges as a result of interpretation a metaphor's associative basis and its reference to cultural etalons and stereotypes. Undoubtedly, metaphor is anthropologic by its nature and to think metaphorically is an exclusively homo sapiens capacity ${ }^{4}$. Thus, metaphor is an inevitable mental, language and culture element that extends and coins new senses and demonstrates a tight link of individual experience with culture and language community experiences ${ }^{5}$.

Following G. Lakoff and M. Johnson, "a culture may be thought of as providing, among other things, a pool of available metaphors for making sense of reality"; "to live by a metaphor is to have your reality structured by that metaphor and to base your perceptions and actions upon that structuring of reality". ${ }^{6}$ This is related to the fact that people of a given culture use language to reflect their attitudes towards the world in general and the life of the community they live in particular. This in turn gives rise to the reason for the argument in favor of a cognitive approach in translating conceptual metaphors, which takes into account cultural beliefs and values especially between culturally distinct languages, like English and Ukrainian.

It is important to distinguish the way we conceive metaphorically of such things as life and death from the way a particular poet may express such thoughts in language ${ }^{7}$. General conceptual metaphors are not the unique creation of individual poets, but are rather part of the way members of a culture have of conceptualizing their experience. Poets, as members of their cultures, naturally make use of these basic conceptual metaphors to communicate with other members, their audience. However, using the mechanisms of everyday thought, poetic mind extends them, elaborates them and combines them in ways that go beyond the ordinary.

\section{Cognitive equivalence in conceptual metaphors translation}

In cognitive linguistics, metaphor is often given a cognitive function in which human beings draw upon the experience of each other or non-

\footnotetext{
${ }^{4}$ Маслова В. А. Лингвокультурология: учеб. пособие / Валентина Авраамовна Маслова. М. : Академия, 2001. С. 92.

${ }^{5}$ Опарина Е. О. Исследование метафоры в последней трети ХХ века / Е. О. Опарина // Лингвистические обзоры в конце XX века. М. : Институт языкознания РАН, 2000. С. 200.

${ }^{6}$ Lacoff G., Johnson M. Metaphors We Live By / G. Lacoff, M. Johnson. Chicago: The University of Chicago Press, 1980. P. 12.

${ }^{7}$ Lacoff G., Turner M. More than cool reason: a field guide to poetic metaphor / G. Lacoff, M. Turner. Chicago: University of Chicago Press, 1989. P. 16. 
human surroundings or even other concepts or images. G. Lakoff and M. Johnson (1980) define metaphor as a means to understand one domain of experience (the target domain) in terms of another, a familiar one (source domain). This usually takes the form of analogy or comparison between two existent entities or one existent entity and another one assumed to exist. To say that someone is a 'lion', for example, reveals that a link has been established between that individual (tenor) and the 'lion' (vehicle) as a symbol of bravery or strength. Therefore, metaphors are 'conceptual' phenomena in which the source domain is mapped onto the target domain. To put it differently, the structural components of the source conceptual schema are transferred to the target domain ${ }^{8}$.

A distinguishing characteristic of recent multileveled theories of translation equivalence is a focus on semantic components, i.e. pragmatic, semantic and syntactic aspects. Besides, a pragmatic component refers to the sphere of adequacy, while semantic and syntactic ones define translation equivalence ${ }^{9}$.

Conceptual metaphor equivalence in a literary text cannot be included into any known level of the equivalence theory. Though this category proves to be semantic either, it also contains linguistic and psychological components on a pragmatic equivalence level. Basically, the majority of equivalence theories do not put to the fore an imagery language component. Meanwhile a conceptual equivalence specification in a literary text enables to take into account psychological and cognitive language aspects that define not only modes of imagery in a text, but modes of thinking in general. For instance, an association, objectified in conceptual codes, combines single concepts into a conceptual sphere, or equivalence of target language and source language references on the level of senses and perception codes predicts psychological impact on a recipient.

O. A. Yasynetska in her study of metaphor translation as a means of conceptual picture representation points out that most proponents of cognitive theory of metaphor consider entirely its conceptual level in two languages, totally neglecting a language level of metaphor realization in them. However, the reproduction of senses and images, not meanings, proves to be a necessary condition of metaphor translation ${ }^{10}$.

${ }^{8}$ Lacoff G., Johnson M. Metaphors We Live By / G. Lacoff, M. Johnson. Chicago: The University of Chicago Press, 1980. P. 34.

${ }^{9}$ Newmark P. Approaches to Translation / Peter Newmark. Oxford : Pergamon Press, 1981. P. 45 .

10 Ясинецька О.А. Переклад метафори як мовна репрезентація концептуальних картин світу / О.А. Ясинецька // Філологічні трактати. 2010. Т. 2. № 1. Вид-во СумДУ С. 96. 
A culture factor can play a crucial role in the way metaphors of one language are translated into another due to various modes of perception and categorization pertain to different language communities. It is thought that there is no simplistic general rule for the translation of metaphor, but the translatability of any given SL metaphor depends on 1) the particular cultural experiences and semantic associations exploited by it; and 2) the extent to which these can, or cannot, be reproduced non-anomalously into the TL, depending on the degree of overlap in each particular case ${ }^{11}$.

This view of culture suggests that, when translating a text of any other culture, one needs to be aware not only of the patterns of thinking, and acting in one's own culture, but also of the TL's cultural models of reality. E. Nida described the 'best' translation as the one capable of evoking in the TL reader the same response as the SL text does to the SL reader. ${ }^{12}$ Although this seems to be a rather unreachable objective, some of it can be achieved provided that the following two conditions are satisfied. First, the translator must understand the way in which receptive readers perceive the world and structure their experience. Second, s/he must also try their best to find a way to accommodate a text to the experience of the targetlanguage reader, and to the way it is recoded in the TL. An argument in favor of a cognitive approach to the translation of metaphors derives from the notion of 'cognitive equivalence', where metaphors can be translated from one language to another with a minimum degree of loss. ${ }^{13}$ For this reason, metaphors are thought to be looked at as cognitive constructs rather than mere linguistic entities ${ }^{14}$. Hence, it remains essential to regard their semantic associations, typical of a given language. In other words, metaphors represent instances of how people conceptualize their experience and how they record it verbally in their language.

In accordance with a cognitive approach to metaphor translation, a culture component that underlies a conceptual metaphor enables to reveal differences in how various cultures constrain human experience. The hypothesis is built on two scenarios:

1) if a conceptual mapping from one domain onto another is similar in a TL metaphor, then a conceptual shift does not occur;

\footnotetext{
${ }^{11}$ Katan D. Translating Cultures: An Introduction for Translators, Interpreters and Mediators / D. Katan. Manchester : ST Jerome Publishing, 1999. P. 28.

${ }^{12}$ Nida E. Towards a Science of Translation / E. Nida. Leiden: E. J. Brill, 1964. 287 p.

${ }^{13}$ Mandelblit N. The Cognitive View of Metaphor and its Implications for Translation Theory. Translation and Meaning / N. Mandelblit. Maastricht : Universitaire Press, 1995. P. 483495.

${ }^{14}$ Kövecses Z. Metaphor and Emotion: Language, Culture and Body in Human Feeling / Z. Kövecses. Cambridge: Maison des Science de L'Homme and Cambridge University Press, 2000. P. 14.
} 
2) if a conceptual mapping from one domain onto another is different in a TL metaphor, then a conceptual shift occurs.

Doing translation within the earlier mentioned scenarios, it is possible to define commonalities in metaphors functioning in different languages along with a 'degree' of their cultural distance.

P. Newmark suggested his classification of the possible ways of metaphor translation:

1) an image reproduction in a TL (natural to a recipient language);

2) a SL image substitution by a standard TL image (equivalent metaphor substitution);

3) a metaphor rendering by means of simile (when image is preserved, but lower degree of expressiveness is inevitable);

4) a metaphor rendering by means of simile, accompanied by a vast explanation (which assists comprehension, but leads to a loss of expressiveness);

5) a reproduction of metaphoric meaning through a paraphrase (when a metaphor is obscure or excessive in a TL);

6) a metaphor omission in case it is unnecessary;

7) a metaphor reproduction and its meaning specification that intensifies an image ${ }^{15}$.

For the translation of conceptual metaphors V. Nikonova proposed specific linguistic and cognitive mechanisms amid which she singles out extension, restriction, amelioration, degradation, questioning and combination of the content of correlating metaphor concept ${ }^{16}$.

In "Cognitive Translation Hypothesis" N. Mandelblit proposed two schemes of cognitive mapping conditions (i.e. Similar Mapping Condition (SMC) and Different Mapping Condition (DMC)). The author intended to show that "the difference in reaction time is due to a conceptual shift that the translator is required to make between the conceptual mapping systems of the source and target languages. She found out that metaphorical expressions take more time and are more difficult to translate if they exploit a cognitive domain different from that of the target language equivalent expression. According to the hypothesis, the reason for this delay, difficulty and uncertainty in the translation of different domain metaphors is the search for another conceptual mapping (i.e. another cognitive domain). That is to say the fact that metaphors almost always exploit such different cognitive domains implies the search for a cognitive

\footnotetext{
${ }^{15}$ Newmark P. The Translation of Metaphor / P. Newmark // Babel, 1980. P. 93-100.

${ }^{16}$ Ніконова В. Г. Реконструкція концептуальної метафори: ідентифікація концептукореляту (на матеріалі трагедій В. Шекспіра) / В. Г. Ніконова // Нова філологія: зб. наук. праць. Запоріжжя: ЗНУ, 2007. № 31. С. 41-44.
} 
equivalence for SL metaphors in the TL. In other words, the translator is called upon to play the role of a proxy agent doing the act of conceptual mapping on behalf of the TL reader. If they can touch upon a similar TL cognitive domain, then their task will be fulfilled quite successfully and easily. If not, they have to look for the cognitive domain that fits in the TL as the SL one does. The result of the first action is often an equivalent TL metaphor or - under the worst conditions - a TL simile. The result of the second action, however, is open to many possibilities, of which rendering the SL metaphor into a TL one is the least likely. Thus, a metaphor might be rendered into a simile, a paraphrase, a footnote, an explanation or - as a last resort - it can be omitted ${ }^{17}$.

Therefore, the attempts of literal rendering or mere linguistic meaning transference of the metaphoric expressions from one language to another are deemed to result in a noticeably bad product, especially when these expressions draw on culture-specific methods of thinking rather than on shared or universal notions.

Referring to cultural aspects and drawing on the general guidelines of the cognitive framework (i.e. the cognitive equivalent hypothesis) for metaphor translation, we used two sets of original English and translated Ukrainian poetic metaphors. The first set comprises metaphors of similar mapping conditions reflecting shared ideas, but verbalized differently in the TL (expressed by different lexical items). The second set contains metaphors of different mapping conditions, which lack conceptual equivalents in the TL.

\section{Metaphors of similar mapping conditions but verbalized differently in Byron's original poetry and its Ukrainian translations}

This group includes metaphors, verbalizing basic concepts of LIFE, LOVE, TIME and DEATH that are characteristic of any language. They represent common conceptual mechanisms of their creation both in original poetical texts and their Ukrainian translations.

SL “Oh, Snatched Away in Beauty's Bloom” Oh! Snatched away in beauty's bloom, On thee shall press no ponderous tomb; But on thy turf shall roses rear Their leaves, the earliest of the year; And the wild cypress wave in tender gloom.

TL “Зірвали дивний першоцвіт” Зірвали дивний першоцвіт, Затис його могильний лід. Але крізь прах життя зроста - Троянд

\footnotetext{
17 Mandelblit N. The Cognitive View of Metaphor and its Implications for Translation Theory. Translation and Meaning / N. Mandelblit. Maastricht : Universitaire Press, 1995. P. 483-
} 495. 
розкриваються вуста Під сутінь кипарисних вim. (Translation by V. Bohuslavska)

In this poem a predicative metaphorical construction "on thy turf shall roses rear their leaves, the earliest of the year" represents the author's original metaphor LIFE IS A ROSE, created due the cognitive mechanism of restriction of a basic metaphor LIFE IS A PLANT. In the translated text the same metaphor is reconstructed, but in a genitive metaphorical construction: “але крізь прах життя зроста - троянд розкриваються вуста". Rose is a kind of flower that implicitly indicates the concept of life and love in poetry. The metaphorical comparison is based on a fixed association of the content of a source concept with a meaning of life, love and youth. In Byron's poetry ROSE is capable of regenerating: "roses rear their leaves", while in translation ROSE is personified and transferred into “троянд розкриваються вуста". The translator endues the rose with anthropomorphic characteristics, aimed at the explication of its spiritual nature. It must be said that in Ukrainian poetical texts the method of personification of plants is very common due to the metaphoric paradigm “a person - a plant”, taken from the national folklore.

Metaphors conceptualizing LOVE also belong to those of similar mapping conditions in Byron's original poetry and its Ukrainian translations.

SL "To Caroline" Yet still, this fond bosom regrets, while adoring, That love, like the leaf, must fall into the sear, That Age will come on, when Remembrance, deploring, Contemplates the scenes of her youth, with a tear;

TL “Кароліні" Та з ніжності серие порине у жаль, Бо листям любов опадає, У згадиі відлуниться юні межа, Ї̈ у сльозах виглядаю. (Translation by V. Bohuslavska)

Individual author metaphor LOVE IS THE LEAVE is a subsidiary model within a basic conceptual metaphor LOVE IS A PLANT, actualizing the meaning of fugacious happy moments in life. In original the conceptual metaphor is realized in a metaphorical comparative construction: "That love, like the leaf, must fall into the sear", but in translation it is presented in a genitive metaphor: "бо листям любов onadae". In both cases the author's metaphor implies a polysemantic complex indicating not only an emotional meaning of love, but the motif of ageing (summer is the season of blossoming that verbalizes adolescence, while autumn symbolizes an old age). The latter meaning is reconstructed in the following two lines: "That Age will come on, when Remembrance, deploring Contemplates the scenes of her youth, with a 
tear” - “У згадиі відлуниться юні межа, Ї̈ у сльозах виглядаю” that intensify the meaning of time fleeting.

Similar conceptual modeling is observed in TIME metaphorization in English and Ukrainian.

SL "To Time" Time! On whose arbitrary wing The varying hours must flag or fly Whose tardy winter, fleeting spring, But drag or drive us on to die - Hail thou! who on my birth bestowed Those boons to all that know thee known; Yet better I sustain thy load, For now I bear the weight alone.

TL “До Часу” $O$ часе, твій політ незримий 3 собою все несе, мов пил. Летючі весни, гайні зими Женуть усіх нас до могил. Хай приділив талан жорстокий Мені до віку, часе, ти - Та легші ті вериги, доки Мені самому їх нести. (Translation by D. Palamarchyk)

In this poem time is personified being compared to bird's flight that "drags or drives us on to die" "on arbitrary wing”. At this a special emphasis is put not only on time's continuousness, but its varying nature as well: "the varying hours must flag or fly", where the modal verb must expresses the meaning of obligation, intensifying the image of fatality. The feeling of inevitability is created by the attributive metaphorical constructions "tardy winter", that is associated with death, and "fleeting spring", that is associated with youth, and that have been adequately transferred into "летючі весни, гайні зими" in Ukrainian translation. The DEATH IS WINTER metaphor is a natural metaphoric conception of life and death, since spring is the season when new plant and animal life is born, while winter signals the dormancy or hibernation of plants and animals. However, life and death are such all-encompassing matters that there can be no single conceptual metaphor to comprehend them.

TL "When Coldness Wraps This Suffering Clay" Above or Love Hope - Hate - or Fear, It lives all passionless and pure: An age shall fleet like earthly year; Its years as moments shall endure. Away - away without a wing, O're all - through all - its thought shall fly, A nameless and eternal thing, Forgetting what it was to die.

SL “Коли Позаземна Зима” Понад Любов, Надію, Жах Жагою чистою зорить. І плине час, i де межа - Роки для Вічності, як мить. Вперед, вперед - хоча без крил - Крізь простір дух сяга глибин, Він незбагненне підкорив, Дарма, щчо мав померти він.(Translation by V. Bohuslavska)

A TIME IS SOMETHING MOVING metaphor has two versions: in both we are located at the present and are facing towards the future with the past at our back. In the original and translation we understand change of time as change of location: "Away - away - without a wing" “Виеред, вперед - хоча без крил" as resulting from an action by an 
agent. The agent is identical to a bird and time is winged, being personified it can fly.

Our understanding of life and death is very much bound up with our understanding of time. This is because death is inevitable and because the mere passage of time can be seen as bringing about inevitable events. One of major cultural models of life is that each of us is allotted a certain fixed time on earth. According to the conventional metaphor of death as departure, we conceive of death as departure away from here, without possibility of return, on a journey, perhaps in a vehicle ${ }^{18}$. We may take it that Byron uses this metaphor, but filling in the slots, that is elaborating it, in an interesting way.

SL "Sun of the Sleepless" Sun of the sleepless! melancholy star! Whose tears beam glows tremendously far, That show'st the darkness thou canst not dispel, How like art thou to Joy remembered well! So gleams the past, the light of other days, Which shines, but warms not with its powerless rays: A night-beam Sorrow watcheth to behold, Distinct, but distant - clear - but, oh how cold!

TL “Сонце безсонних” Безсонних сонце, зірко жалібна! Твій слізний пломінь криє далина, Безсилий пітьму він перемогти. Як на минуле щуастя схожа ти! Отак нам світить відблиск інших днів, Але не гріє, хоч би як виднів. Так в ніч сумну минувшина зійшла: Хоч видна - та здаля, ясна - та без тепла. (Translation by H. Kochur)

Being away from here is characterized by the specific case of departure. The vehicle is an unusual one - "the moonless air". These ways of making the DEATH IS DEPARTURE metaphor specific add considerable conceptual content to the metaphor of death as departure. Eternal space, after all, in not merely being away from here. It is "rayless and pathless", it is unwanted, it assumes that it is an unusual state when "sun was extinguished" and so on. The moonless air, moreover, is not something that takes us swiftly or securely to a given destination as it is a departure to the unknown. It is something we are not in control of because we are at the whim of the currents, and it leaves us exposed to the elements.

A LIFETIME IS A DAY is a metaphor in which birth is dawn, maturity is noon, old age is twilight, the moment of death is sunset, and the state of death is night. This metaphor implies death's coldness in night's coldness, since death is naturally substituted by night.

LIFE IS A SUN - ЖИТТЯ С СОНЦЕ is implicitly realized both in the original and translation through a combination of associatively linked units

${ }^{18}$ Lacoff G., Turner M. More than cool reason: a field guide to poetic metaphor / G. Lacoff, M. Turner. Chicago : University of Chicago Press, 1989. P. 5. 
that explicitly indicate the Sun's attributes. "Sun of the sleepless!" „Соние безсонних" is a genitive metaphorical construction that contains an extended poetic image of the metaphorical composition, which is realized in the whole text. However, the lexemes, expressing the sun's features, are used in a sharp contrast to all positive meanings via the procedure of questioning of the basic concept. The poet calls the sun a "melancholy star" - “зірка жалібна" which lost its ability to lighten darkness: "Whose tears beam glows tremendously far, That show'st the darkness thou canst not dispel" - "Твій слізний пломінь криє далина, Безсилий пітьму він перемогти". A pessimistic feeling of reality is created by the image of the sun with its powerless rays: "the light of other days, Which shines, but warms not with its powerless rays" - "Отак нам світить відблиск інших днів, Але не гріє, хоч би як виднів". A personified Darkness reins the universe.

\section{Metaphors of different mapping conditions in Byron's original poetry and its Ukrainian translations}

In this section the attempt has been made to establish not only the specificity of metaphors functioning in culturally distinct languages, but to indicate national and cultural components in metaphorical elaborations and extensions. In English and Ukrainian poetic traditions special modes of presenting metaphorical meanings have been formed, which causes semantic and functional divergences in metaphorical conceptualization of some basic universal notions. Despite the similarity of the filters in different languages, i.e. metaphorical analogy that enables metaphorical transformation, their metaphorical presentation does not coincide. As a result associative and image lacunas emerge, which testify to subjective perception and evaluation of the world by different cultural background language communities.

TL "I Saw Thee Weep" I saw thee weep - the big bright tear Came o're that eye of blue; And then methought it did appear A violet dropping dew: I saw thee smile - the sapphire's blaze Besides thee ceased to shine; It could not match the living rays That filled that glance of thine. As clouds from yonder sun receive A deep and mellow dye, Which scarce the shade of coming eve Can banish from the sky,

SL “Я бачу твої сльози” Ти плачеш - адамант сльози Затьмарюе блакить, Краплина росна від грози $B$ барвінку мерехтить. Всміхнешся - спалахом сапрір Сяйне з тремтливих вій. Зустрівши твій промінний зір, Тлумить небо свій. Сховає соние вовна хмар В пухнастій глибині - Чи допоможе хто тягар Підважити мені? (Translation by V. Bohuslavska) 
Metaphorical extension results in the reconstruction of a composition TEAR - DEW - GEM indicating the evaluative component in the emotional poetic image. Thus, the image of sapphire in the original, and added by the translator an image of a diamond in Ukrainian, considerably extends the poetic expression of emotional feeling: "I saw thee smile the sapphire's blaze Besides thee ceased to shine" - "Всміхнешся спалахом сапрір Сяйне з тремтливих вій". Besides, the meaning of first love is implicitly indicated by "a violet" in the English text, which has been correspondingly substituted in the translation by "барвінок" in the line with the national folklore: "A violet dropping dew" - "В барвінку мерехтить".

The metaphorical transformation within a paradigm "an atmospheric phenomenon" - "a substance" lies in the basis of CLOUDS ARE WOOL metaphor in the Ukrainian translation. The nominal construction "вовна $x_{\text {мap" }}$ is built on the principle of subjectivity. The clouds are seen as soft substances creating the poetic illusion as if they were alive.

Byron's poetry often reveals fascination with the natural world. The poet writes perceptively of trees and flowers, oceans and rivers and uses lucid metaphors to describe the sky and the sea. This wonderful balance between imagination and observation is, in many ways, what makes Byron's verse the perfect hook for a life-long appreciation of poetry.

His nature poems divide into those that are chiefly presentations of scenes appreciated for their liveliness and beauty, and those in which aspects of nature are scrutinized for keys to the meaning of the universe and human life. The distinction is somewhat artificial but still useful, for it will encourage consideration of both the deeper significances in the more scenic poems and of the pictorial elements in the more philosophical poems. As we have noted, nature images and metaphors permeate Byron's poems on other subjects and some of those poems may be more concerned with nature than at first appears.

The personification of an atmospheric phenomenon is laid in the poetic image of wind in the Ukrainian translation.

SL "Stanzas For Music" There be none of Beauty's daughters With a magic like thee; And like music on the waters Is thy sweet voice to me: When, as if its sound were causing The charmed Ocean's pausing, The waves lie still and gleaming, And the lulled winds seem dreaming: And the midnight Moon is weaving Her bright chain o'er the deep; Whose breast is gently heaving. As an infant's asleep: So the spirit bows before thee, To listen and adore thee; With a full but soft emotion, Like the swell of Summer's ocean. 
TL “Станси під музику” Ніхто із донь краси земної Не збурює

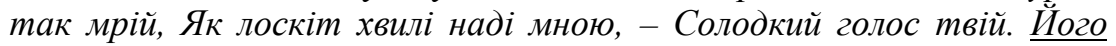
чарівний звук лунає, Приборкуючи моря гомін, I зоряний принишклий промінь На спині вітру засинає. I місяиь у сріблясті персні Хвилини засиля. I дихають світи небесні, Мов сонне немовля. Мій дух, мов райдуга до неба, Здіймається для тебе. Обожнюю, лечу до вирію В маю морською хвилею. (Translation by V. Bohuslavska)

The extended metaphor WIND IS A LIVING BEING THAT SINGS CRADLE SONGS is reconstructed in the Ukrainian translation under the strong influence of national folklore. The metaphorical concept is represented explicitly in the genitive construction "На спині вітру засинає". The latter is based on the principle of personification of the air. The predicative construction "Його чарівний звук лунає" explicates the meaning of a cradle song along which “моря гомін” and "принишклий промінь засинають". The poetic metaphor creates an illusion of nature similar to a human world.

Mixed feelings of a different kind are striking in Byron's many poems about storms with (and occasionally without) rain. The details of the scene are presented in a series of vigorous personifications and metaphors. The wind is rising and sweeping across the land. Its force makes some of the grass stand up high and some lie down. The description of leaves unhooking themselves and dust scooping itself animates the landscape and conveys a sense of excitement about the release of power. Lightning is a giant bird whose head and toe stand for its jagged sweep.

A POET IS A BIRD metaphor represents Byron's original association of himself with a bird: "A bird of free and careless wing Was I". In the Ukrainian translation this metaphor has been specified in a comparative construction: „О, як мені з душного світу Мов голуб до свого кубла У небо грозове злетіти". In this context a special attention should be paid to the image of the concept of SNARE in the original and ГНІЗДО in the translation. The poet calls himself " $a$ bird caught within the subtle snare", that is being associated with a bird, the author puts forward the meaning of losing his freedom, caused by love.

Birds putting up bars to nests humanize their actions and parallel the behavior of people. All the images of flight thus far, including the description of the landscape, build up a tension which begins to ease with the description of the drop of giant rain.

Byron's more philosophical nature poems tend to reflect darker moods than do his more descriptive poems and are often denser and harder to interpret. The nature scenes in these poems often are so deeply internalized in the speaker that a few critics deny the reality of their physical scenes 
and insist that the poems deal exclusively with states of mind. Despite their relative brevity, Byron's philosophical nature poems are often quite rich in meaning and connotation, and they can be re-read and reexperienced from many angles.

PEOPLE ARE PLANTS. In this metaphor, people are viewed as plants with respect to the life cycle - more precisely, they are viewed as that part of the plant that burgeons and then withers or declines, such as leaves, flowers, and fruit, though sometimes the whole plant is viewed as burgeoning and then declining, as with grass or trees.

The stages of the plants and parts of plants in their yearly cycle correspond to the stages in life. When we speak of someone as a "young sprout", we mean that he is in the early stages of life. Someone "in full bloom" is mature. Someone "withering away" is approaching death. Thus, in Byron's poetry we can apply the PEOPLE ARE PLANTS metaphor to read "Stanzas to Augusta":

SL "Stanzas to Augusta" Thou stood'st, as stands a lovely tree, That still unbroken, though gently bent, Still waves with fond fidelity Its boughs above a monument.

TL “Станси до Августи” Кохання деревцем гінким Обом нам зав'язало світ. Обоє ми - його гілки У вічності квітучих віт. (Translated by V. Bohuslavska)

The metaphoric image is created in the line with a fixed folklore association of love with a tree on the one hand "Кохання деревцем гінким Обом нам зав'язало світ", and a human being - on the other hand: “Обоє ми - його гілки У вічності квітучих віт”. A tree in blossom symbolizes a person in love, a specific harmony of man with the surrounding world.

TL "Stanzas to August" In the Desert a fountain is springing, In the wide waste there still is a tree, And a bird in the solitude singing, Which speaks to my spirit of Thee.

SL “Станси до Август” Джерельие у пустелі дивовижне, І солоспів самотній солов'я, $У$ спеку степову розквітлу вишню I звістку, щзо несе душа твоя. (Translated by D. Palamarchuk)

The poetic image of life in the desert is realized by means of a chain of metaphoric compositions, in which numerous elaborations and cognitive mechanisms of extensions have been made in the Ukrainian translation. Thus, an English "fountain" has been rendered as "джерельие”, a "treе" has been modified into "розквітлу вишню", and finally "a bird in the solitude singing” has been specified into “солоспів самотній солов'я”.

The same instances of modification of some basic concepts are observed in the following poem: 
TL “Stanzas for Music" Light be the turf of thy tomb! May its verdure like emeralds be! There should not be the shadow of gloom In aught that reminds us of thee. Young flowers and an evergreen tree May spring from the spot of thy rest: But nor cypress nor yew let us see; For why should we mourn for the blest?

SL “Станси під музику” Надгробок твій з промінних трав! Росу смарагдами гойдає. Тут морок дрібку світла вкрав, Яка про тебе нагадає. Весняні квіти, зелен-лист Твій відпочинок вкрили тінню. Та де верба, де кипарис? - Де виплачу благословення? (Translated by V. Bohuslavska)

Byron's "young flowers" have been substituted by "весняні квіти”, “an evergreen treе" has been rendered as“зелен-лист”. Moreover, there is a case of extension of a poetic image in the translation by adding a definite type of a tree: "But nor cypress nor yew let us see" - "Та де верба, де кunapuc?” A number of poems reveal that Byron regarded nature as being invested with symbolic and sacred meaning, indeed, that it could be the symbolic instrument of spirit, capable of conveying grace and assurance of spiritual regeneration.

\section{CONCLUSIONS}

The use of metaphor in poetry can hardly be avoided. First, it enables the author to squeeze multiple images and complex senses into a dense space due to the architectonics of a poetic genre. Second, metaphor can structure a verse itself. Metaphor can be described as figure of speech in which a thing is referred to as being something that it resembles. In this way, metaphors are used in poetry to explain and elucidate emotions, feelings, relationships other elements that could not be described in ordinary language. Poets also use metaphor as a mode of explaining or referring to something in a brief but effective way.

There is no simplistic general rule for the translation of metaphor, but the translatability of any given SL metaphor depends on 1) the particular cultural experiences and semantic associations exploited by it; and 2) the extent to which these can, or cannot, be reproduced non-anomalously into the TL, depending on the degree of overlap in each particular case.

What determines the translatability of a SL metaphor is not its "boldness" or "originality", but rather the extent to which the cultural experience and semantic associations on which it draws are shared by speakers of the particular TL. Moreover, the inherent difficulty of metaphor translation is not the absence of an equivalent lexical item in the TL, but rather the diversity of cultural conceptualization of even identical 
objects or worlds in both communities whose languages are involved in translation.

In the research done conceptual metaphors in Byron's original poetry and its Ukrainian translations have been studied from two perspectives. Firstly, the major modes of poetic metaphors elaboration have been examined. As it has been illustrated, poetic thought extends and elaborates conventionalized metaphors via the mechanisms of extending, elaborating, questioning, composing and personification. The latter mode is probably the most effective and frequently used in Byron's poetry since personification permits us to use our knowledge about ourselves to maximal effect, to use insights about ourselves to help us comprehend such things as forces of nature, common events, abstract concepts, and inanimate objects.

Secondly, in accordance with Mandelblit's "Cognitive Translation Hypothesis" poetic metaphors have been divided into two groups:

1) metaphors of similar mapping conditions but verbalized differently in the Ukrainian translations. Although Byron's original metaphors and their Ukrainian counterpart metaphors belong to the same conceptual domain, the ethnical and cultural system has led to major differences in lexical choices.

2) metaphors of different mapping conditions. This group includes cases of English poetic metaphors the image of which cannot be reproduced in the TL. Therefore, the translator has no choice other than replacing the SL image with a TL image that does not clash with the target culture. This can only be done by resorting to the strategy of different cognitive mapping in search for cognitive equivalence.

\section{SUMMARY}

The research is dedicated to the study of conceptual metaphors and modes of their elaboration in Byron's original poetry and its Ukrainian translations. It is firmly believed that basic conceptual metaphors reflect the universal principles of encoding human experience in language. In poetry conventional metaphors undergo the mechanisms of elaboration that extend the content of a correlating concept, illustrating culturally specified nature of metaphor. In a line with this the translation of conceptual metaphors proves to be heavily conditioned by culture aspect, embodied in a text with purposefully selected language means or images that accumulate national traditions and folklore. 


\section{REFERENCES}

1. Байрон Дж. Г. Лірика / Дж. Г. Байрон ; [упор. і пер. 3 англ. Д. Паламарчук]. К. : Дніпро, 1982. 150 с.

2. Байрон Дж. Г. Твори / Дж. Г. Байрон ; [пер. 3 англ. В. Богуславської]. К.: Дух і Літера, 2004. 366 с.

3. Кочур Г. Третє відлуння / Григорій Кочур. К. : Рада, 2000. C. 57.

4. Маслова В. А. Лингвокультурология: учеб. пособие / Валентина Авраамовна Маслова. М. : Академия, 2001. 204 с.

5. Ніконова В. Г. Реконструкція концептуальної метафори: ідентифікація концепту-кореляту (на матеріалі трагедій В. Шекспіра) / В. Г. Ніконова // Нова філологія: зб. наук. праць. Запоріжжя: ЗНУ, 2007. № 31. C. 41-44.

6. Опарина Е. О. Исследование метафоры в последней трети XX века / Е. О. Опарина // Лингвистические обзоры в конце XX века. М. : Институт языкознания РАН, 2000. С. 186-203.

7. Ясинецька О.А. Переклад метафори як мовна репрезентація концептуальних картин світу / О.А. Ясинецька // Філологічні трактати. 2010. Т. 2, № 1. Видавництво СумДУ. С. 96-100.

8. Byron G. Selections From Byron. Lyrical Verse / G. Byron. Moscow: Progress Publishers, 1979. 520 p.

9. Gibbs R. W. The Poetics of Mind: Figurative Thought, Language and Understanding / R. W. Gibbs. Cambridge: Cambridge University Press, 1999. 527 p.

10. Katan D. Translating Cultures: An Introduction for Translators, Interpreters and Mediators. Manchester: ST Jerome Publishing, 1999. 302 p.

11.Lacoff G. The Contemporary Theory of Metaphor / G. Lacoff // Metaphor and Thought / Ed. by Andrew Ortony. 2-nd edition. Cambridge: Cambridge University Press, 1993. P. 202-251.

12. Lacoff G., Johnson M. Metaphors We Live By / G. Lacoff, M. Johnson. Chicago: The University of Chicago Press, 1980. 240 p.

13. Lacoff G., Turner M. More than cool reason: a field guide to poetic metaphor / G. Lacoff, M. Turner. Chicago: University of Chicago Press, 1989. P. 16.

Newmark P. Approaches to Translation / Peter Newmark. Oxford: Pergamon Press, 1981. 230 p.

14. Mandelblit N. The Cognitive View of Metaphor and its Implications for Translation Theory. Translation and Meaning / N. Mandelblit. Maastricht : Universitaire Press, 1995. P. 483-495.

15. Newmark P. Approaches to Translation / Peter Newmark. Oxford : Pergamon Press, 1981. 200 p. 
16. Newmark P. The Translation of Metaphor / Peter Newmark // Babel, 16: 2. 1980. P. 93-100.

16. Nida E. Towards a Science of Translation / E. Nida. Leiden: E. J. Brill, 1964. 287 p.

17. Quinn N. The cultural basis of metaphor / N. Quinn // Beyond metaphor: the theory of tropes in anthropology. Stanford, 1991. P. 56-93.

\section{Information about the author:} Chendey N. V., Candidate of Philological Sciences in Comparative Linguistics, Associate Professor at the Department of English Philology, Uzhhorod National University 14, Universytetska str., Uzhhorod, 88000, Ukraine 